\title{
Micromorphological variation forage crops of Loliinae subtribe (Poaceae)
}

Maryam Keshavarzi ( $\square$ neshat112000@yahoo.com )

Alzahra University https://orcid.org/0000-0003-3032-9408

\section{Raheleh Tabaripour}

Alzahra University

\section{Original Article}

Keywords: Loliinae, micromorphology, silica bodies, lemma, palea, epicuticular wax.

Posted Date: May 5th, 2020

DOl: https://doi.org/10.21203/rs.3.rs-20606/v2

License: (c) (1) This work is licensed under a Creative Commons Attribution 4.0 International License. Read Full License 
The authors have withdrawn this preprint from Research Square 